\begin{tabular}{|c|c|c|c|}
\hline & \multicolumn{2}{|c|}{ R\&S - RESEARCH STUDIES ANATOLIA JOURNAL } & $=$ \\
\hline Anatolia Journal & www.dergipark.gov.tr/rs & Vol: 1, Issue: 2, pp.344-351 & \\
\hline
\end{tabular}

Ordun, G. ve Akün, F. A. (2018). "Hatalı Karar Bağlılığı: Y Kuşağıyla İlgili Bir Araştırma”, R\&S - Research Studies Anatolia Journal, Vol:1, Issue:2; pp: 344-351

\begin{tabular}{ll}
\hline \hline $\begin{array}{l}\text { Anahtar Kelimeler: Hatalı Karar Bağ lılığı, Duygusal } \\
\text { Zekâ, Kişilik, Öz Yeterlilik, Y Kuşağı }\end{array}$ & $\begin{array}{l}\text { Keywords: } \\
\text { Intelligence, Personalion of Commitment, Self Efficacy, Y Generational }\end{array}$ \\
\hline \hline
\end{tabular}

Makale Türü: Araştırma Makalesi

\title{
HATALI KARAR BAĞLILIĞI: Y KUŞAĞIYLA İLGİLİ BİR ARAŞTIRMA*
}

\author{
Escalation of Commitment: A Research on Y Generation \\ Doç. Dr. Güven ORDUN \\ İstanbul Üniversitesi İşletme Fakültesi, gordun@istanbul.edu.tr Istanbul/Türkiye
}

Ar. Gör. F. Aslı Akün

İstanbul Üniversitesi İşletme Fakültesi, asli.akun@istanbul.edu.tr

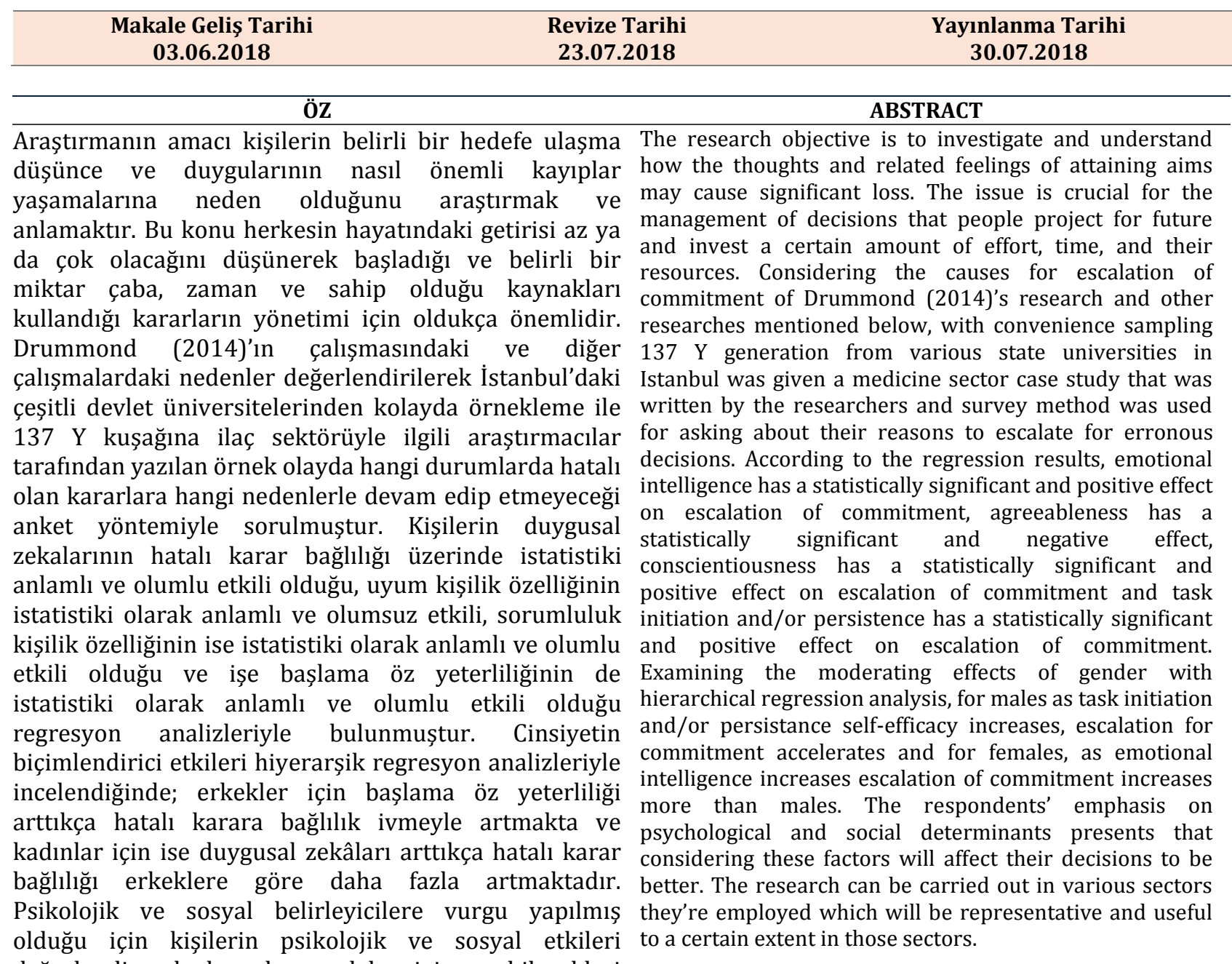

değerlendirerek kararlarını daha iyi verebilecekleri anlaşılmaktadır. İstihdamlarıyla ilgili çeşitli sektörlerde yapılacak araştırmalar sektörel olarak belirli bir ölçüde temsil edici ve yararlı olabilir.

\footnotetext{
* IV. Asos Kongresi'nde sunulan bildirinin genişletilmiş tam metnidir.
} 


\section{GíRiş}

Gündelik hayatta her bir birey hayatlarındaki pek çok konuya ilişkin sayısız kararlar verirler. Luthans (2011-278-280)'ın aktardığı üzere evrensel olan, karar vermenin iki ya da daha fazla alternatif arasında seçim yapmak olduğudur. Ayrıca, karar yollarının istenilen sonuca varmasının kararın rasyonelliğiyle ilgili olduğunu belirtmiştir. Ancak, karar yollarını amaçlardan ayırırken öncelikli bir amacın daha büyük bir amaç için araç olabilecek olmasının; bir diğer deyişle, araçlar sonuçlar hiyerarşisi/zincirinin, Asch'in gruba uyum deneyinde olduğu gibi karar vermede sosyal etkinin olmasının ve siyah ya da beyaz gibi karar verme durumlarında uyum sağlayan grilerin olmasının kararın rasyonelliğini zorlaştırdığını anlatmıștır.

Nobel ödüllü Kahneman (2017: 25-485) Hızlı ve Yavaş Düşünme adlı kitabında karar vermede Sistem 1 ve Sistem 2 geçişlerinin önemini anlatmıştır. Sistem 1'in günlük yaşamımızda karşılaștığımız olayları/kişileri/ilişkileri hızlıca algılamamızı, tanımamızı ve anlamamızı sağladığını; Sistem 2'nin ise hazırlanma, odaklanma, düzenleme ve karar vermede etkili olduğunu belirtmiștir. Bu nedenle her ikisinin de önemli olduğunu ancak bilişsel yük/zorluk altında kendine kontrol uygulamanın daha çok endișeye, etkisiz ve/veya yeterli olmayan performansa, hedeften sapmaya, tutum yönelimli olmaya, karşıtlıklarda sakinliğini yitirmeye, ego tükenmesi; zorlukları çözmek için iç enerji bulabilip süreci devam ettirememeye, daha az zahmetli ve ayartıcı durumlara zafiyete neden olabileceğini ve bu sorunları dikkate almanın ve tüm olasılıkları ve bilgiyi değerlendirmenin önemine değinmiştir.

Karar verme konusuyla ilgili olarak bu araştırmanın amacı, çeşitli nedenlerle iyi karar vermenin zorluğuyla ilgili olarak özellikle yabancı alanyazında vurgulanmış hatalı karar bağlılığını açıklamak ve bu konuyla ilgili araştırma yapmaktır.

\section{HATALI KARAR BAĞLILIĞI}

Staw ve Ross (1987: 39-78) hatalı karar bağlılığının (escalation of commitment) iş / proje özellikleri, psikolojik, sosyal ve örgütsel nedenler olmak üzere dört boyutta açıklandığını belirtmektedir. Alvarez vd. (2011: 971-981) çalışması hayatta kalanlar ve gözlemleyenlerin yayınladıkları biyografilerden 1996 yılında Everest tırmanış yolculuğunda bu hatanın sekiz kişinin ölümüyle sonuçlanan bir felakete nasıl dönüștüğünü ve dinamikler iyi değerlendirilirse yönetilebilir bir olgu olduğunu anlatmak istemiştir. Çalışmalarında Staw ve Ross'un belirleyicilerine göre açıladıkları hatalı karar bağlılığı nedenleri; proje açısından geçici örgütlenmelerin durumunun projenin başarısına bağlı olduğu için başarısızlığın bedelinin yüksek olması, psikolojik açıdan teşvik tuzaklarına düşme ve kararın doğruluğunu ispatlama isteği, özveriler, umutlar, geçmişteki başarılar, sorumluluk duygusu, öz değer, öz güven, benlik ve beklentilerle zirveye çıkmaya kilitlenmesi, sosyal açıdan takımlar arası rekabet ve örgütsel açıdan da misyonlarını gerçekleştirme ve gelişimdir.

Sleesman vd. (2012: 543) Staw ve Ross'ın belirleyicilerini ve geçmiş araştırmalardaki bulguları sentezleyerek, proje belirleyicilerinden karar riski ve potansiyel kayıpları anlayabilme, firsat maliyet bilgisi ve alternatifleri değerlendirebilme ve bilgi edinerek kararın zayıf yönlerini görmenin bu hatayla olumsuz ilişkiliyken, belirsizlik, geçmiş olumlu performans eğilimi ve verilen yanlış kararın kişinin kendi tercihi olmasının olumlu ilişkili olabildiğini belirtmiştir. Psikolojik belirleyicilerden deneyim / uzmanlık, öz güven / öz yeterlilik, hatalı kararda kişisel sorumluluk ve olumlu benlik algısının tehdit edilmesinin insanların kayıplarını görmek istememelerine, kendilerini doğrulamak üzere olumsuz geri bildirimi görmezden gelmelerine ve kendilerini ve kararlarını haklı görmelerine neden olarak hatayla olumlu ilişkili olabildiğini ortaya koymuştur. Pişman olmama isteğinin kendini haklı çlkarmayı azaltarak ısrarla olumsuz ilişkili, bilginin nasıl sunulduğunun risk algısını etkilediği ve sonuca ulaşmaya yakınlığın devam etmeyle olumlu ilișkili olabildiğini belirtmiștir. Sosyal belirleyicilere göre, kararın çevre tarafından değerlendirilecek olmasının ve grup birlikteliğinin olumlu ilişkili, başkalarının kararlarına direnmenin ise olumsuz ilişkili olabildiğini belirtmiştir. Yapısal belirleyicilere göre, karar vermenin vekâletini taşıyan kişilerin kendi isteklerini ön plana almasının olumlu ilişkili olabileceğini ortaya koymuștur.

Bu olguyu araştıran ve yöneticilerle yapılan bir araştırma (Chong ve Syarifuddin, 2010: 11-12) uyum baskısı ve öz güvenin yöneticilerin değerlendirmelerindeki etkisini incelemiş ve proje müdürlerinin uyum altında hatalı karar bağlılı̆̆ını arttırdığını ve öz güveni yüksek olanların daha fazla devam etme eğilimi olduğunu ortaya koymuştur. Bu bulguyla işletmelerde proje müdürlerinin böyle baskılara kaşı koyabilecek kontrol mekanizmaları geliştirilmesinin yararlı olduğu belirtilmiștir.

Ku (2008: 224-230) bu hatayı azaltıcı yararlı bir karar müdahalesi olarak pişmanlığın önemine değinmiştir. Pişmanlığın beklenmedik olan ve kişinin kendi dışındaki sonuçların istediği gibi 
olmadığını yansıtan hayal kırıklığından farklı olarak kendi yapmış olduğu seçimleri ve ürettiği sonuçlardan daha iyilerini yapabilecek ancak yapamamış olduğu düşünce ve duygusu olarak tanımlandığını ve pişmanlığın nahoșluğunun düşünce ve davranıș değişikliğine; "Böyle olsaydı" gibi karşı olgusal düşünmeyi teșvik ederek ve "Neleri farklı yapmam gerekirdi?" diye sorgulayarak kişilerin hatalarından öğrenmesine ve hatalar karşısında kazandıkları derin anlayışla aynı hataya düşmemelerine neden olabileceğini aktarmıştır. Kendi araştırmasının sonuçları, pişmanlığın hatalı karar bağlılığını azaltıcı etkisini ortaya koymuştur.

Drummond (2014: 430-438)'de insanların ve işletmelerin girişimleri ve yatırımları için karar verirken zorluklarla karşılaştığında bazen yine de devam etmenin bazen de devam etmemenin daha iyi olabileceğini ancak kișilerin bazen daha çabuk bazen ise daha geç vazgeçtiğini belirtmiș ve bunun nedenlerini açıklamıştır. Așırı güven, batık maliyetler, kararlarını kendilerine doğrulama isteği, inkâr ve savunma, sosyal maliyetler, tamamlama etkileri ve organizasyonun çıkış engeli hatalı kararlara devam etme nedenleri ve kayıptan kaçınma, belirgin firsat maliyetlerini değerlendirme, devamlılı̆̆ın algılanan riski ve pişmanlık, korku ve şüphelerin aşındırıcıllğı, beklentilerinin karşılanmamasına yönelik tahammülsüzlük, sağlam gözükebilmek için sosyal sınır çizmek, bütçe yenileme isteksizliği ve kişiler ve kişilerarası ilişkilerle de ilgili organizasyonun gelgitleri ise devam etmeme olarak belirtilmiștir. Hatalı terk etmenin ise yeterli destek olmadığında, sorumluluk dağıldığında ve projenin ortasında daha çok olduğu vurgulanmıştır. Algılanan riskin az ve sorumluluğun az olduğu durumda kararsızlık, algılanan riskin çok ve sorumluluğun çok olduğu durumda ise doğru karar almanın en olası olduğuna değinilmiştir.

\section{KIȘİLIKK, DUYGUSAL ZEKÂ, ÖZ YETERLİLİK VE Y KUŞAĞI}

Araștırmanın diğer değișkenleri olan kişilik ve duygusal zekayla ilișkili olarak; örneğin kişilik, kendinizi kısaca nasıl tanımlarsınız sorusuna yönelik olduğu belirtilmiștir (Krogerus ve Tschäppeler, 2014: 18). 1980’lerde Paul Costa ve McCrae'nın Beş Büyük özelliği; dışadönüklük, uyum, sorumluluk, duygusal denge ve deneyime açıklık olarak tanımlandığını aktarmışlardır (Krogerus ve Tschäppeler: 18). Beș boyuttan dıșadönüklüğün az olmasının olumsuz yorumlanabildiğini ancak insanlarla bir arada olmadan da kendini rahat hissetmekle, uyumun ahenkle yaklaşmakla, sorumluluğun sebat eden ve müşkülpesent olmakla, duygusal denge engeller, belirsizlikler ve anlaşmazlıklarla ilgili tepkilerle ve deneyime açılılk ise işler yolunda gittiğinde bile değişik düşünceleri üretmekle ilgili olduğunu belirtmişlerdir (Krogerus ve Tschäppeler, 2014: 18-19). Goleman (1998: 9-39) duygusal zekayı; duyguları okuyabilme, kendini etkili ifade etme ve problem çözebilme, duyguları bastırmadan duygusal sıkıntılar ve dürtülerle etkili baş edebilme, olumsuzluklardan daha az etkilenmeyi öğrenme, çeșitli duygu, düșünce, davranıșları ve farklılıkları etkili yönetme, bireysel ve kolektif popüler ve/veya yıldız olmayla tanımlamıștır. Öz yeterlilik, kișinin istenilen bir duruma ulaşmaya ya da olasılığı yönetmeye yönelik bilişsel, duygusal kaynaklarını kullanabilip gerekli davranışları gösterebileceği için kendine inancı olarak Bandura (2009: 19) tarafından tanımlanmıștır. Y kuşağının dünyada doğum aralığının 1981-2000 (37-18 yaş arası) olduğu (Zemke vd., 2000: 3) ve diğer kuşaklara göre incelendiğinde, Y kuşağında teknolojinin etkilerini anlama ve sağlıklı yaşam uygulamaları benimseme gereği (Deal vd. 2010: 197-198) daha fazla vurgulanmaktadır.

\section{YÖNTEM}

Drummond (2014: 430-437)'ın çalışmalarındaki nedenler ışığında ve yukarıda belirtilen tüm neden ve yaklașımlar doğrultusunda İstanbul'daki çeşitli devlet üniversitelerinden kolayda örnekleme ile 137 Y kuşağına, ilaç üretim aşamalarında iç ve dış çevredeki geribildirimleri ve değişiklikleri nasıl değerlendirecekleri ile ilgili olarak araştırmacıların yazdıkları örnek olayda, riskli, rekabetçi, dezavantajlı ya da olumsuz koşullarda devamı hata olarak düşünüp düşünmedikleri ve hatalı kararlara hangi nedenlerle devam edip etmeyecekleri anket yöntemiyle sorulmuştur. Araştırmada incelenen diğer değişkenler kişilik, duygusal zekâ ve öz yeterliliktir. Araştırmada Beş Büyük Özellikleri ölçen NEO-PI-R'in 10 maddeden oluşan (TIPI) Sam Gosling ve ekibi tarafindan geliştirilen geçerli ve güvenilir kısa formu kullanılmıştır (Krogerus ve Tschäppeler, 2014: 20-21). Araştırmada, duygusal zekayı ölçmek için, kişilerin duygularını tanıması, yeterli ifade etmesi, düzenlemesi ve etkili değerlendirmesiyle ilgili Schutte vd. (1998: 172) Duygusal Zekâ testi kullanılmıştır. Öz yeterliliği ölçmek üzere Sherer vd. (1982: 666) tarafından geliștirilen ve önceki çalışmamızda (Ordun ve Akün, 2017) başlama, mücadele ve sosyal öz yeterlilik olmak üzere üç boyutlu faktör yapısı geçerlik ve güvenirliği değerlendirilerek yararlandığımız öz yeterlilik ölçeği kullanılmıştır. Araştırmamız, kişiliğin, duygusal zekanın ve öz yeterliliğin hatalı karar bağlılığı üzerinde belirlenen örneklemde etkili olup olmadığını araștırmaktadır. Konuyla ilgili araștırmalar incelendiğinde, sorumluluk hissetmek, kendine 
güven ve grup birlikteliği gibi psikolojik belirleyicilerin hatalı karar bağlılığını arttırdığı bilindiği için (örn. Sleesman vd., 2012: 543), kişilik özellikleri olarak sorumluluk, uyum ve diğer özelliklerin ve öz yeterliliğin de etkili olacağı düşünülmüş, duygusal zekâ da bir başka değişken olarak araştırılmak istenmiş ve araştırmanın hipotezleri ortaya çıkmıștır. Bu çalışmadaki değişkenlerle ilişkisini değerlendiren herhangi bir araştırmaya rastlanmamıştır. Öz yeterliliğin Kaiser-Meyer Olkin değeriyle $(\mathrm{KMO}=.80)$ örneklem büyüklüğünün faktör analizi için yeterli olduğu tespit edilmiștir. Bartlett küresellik test değerinin (BKT=971.6, p<.01) anlamlı olması, maddeler arası korelasyonların faktör analizi için uygun olduğunu ortaya koymuştur. Keşfedici faktör analizinde özdeğerler 1'den büyük olacak şekilde üç boyutlu yapıyı ortaya koyduğu ve faktörlerin toplam varyansın \%41.8'ini açıkladığı ve maddelerin faktör yüklerinin .6'nın üzerinde olduğu bulunmuştur (Gürbüz ve Şahin, 2016: 307323). Ayrıca, Kaiser-Meyer-Olkin değeriyle $(\mathrm{KMO}=.70)$ kişiliğin örneklem büyüklüğünün faktör analizi için yeterli olduğu tespit edilmiştir. Bartlett küresellik test değerinin (BKT=161.7, p<.01) anlamlı olması, maddeler arası korelasyonların faktör analizi için uygun olduğunu ortaya koymuştur. Keşfedici faktör analizinde özdeğerler 1'den büyük olacak şekilde beş boyutlu yapıyı ortaya koyduğu ve faktörlerin toplam varyansın \%69'unu açıkladığı ve maddelerin faktör yüklerinin 0.6'nın üzerinde olduğu bulunmuștur (Gürbüz ve Şahin, 2016: 307-323). Değișkenlerin Cronbach Alpha güvenirlik katsayıları; öz yeterlilik için .83, kişilik için .70 ve bu çalışmada tek boyut olarak değerlendirilen duygusal zekâ için .80'dir ve ölçeklerdeki maddeler arasında iç tutarlılıkların yüksek olduğu bulunmuştur. (Gürbüz ve Şahin, 2016: 323-329).

\section{BULGULAR}

Sıklık dağılımlarına göre (Gürbüz ve Şahin, 2016: 205-259) devamlılıkta en az ortalama (Ort=2.71, $\mathrm{SS}=1.18)$ "iç ve dış müşterilerin etkisi ve baskısı nedeniyle devam ederim", devamsızlıkta ise $($ Ort=2.65, SS=1.39) "başarısız olmaya tahammülsüz olduğum için devam etmem" olarak bulunmuştur. Buna göre, katkıları, kendilerine olan güven ve sorumlulukları nedeniyle devam etmek istedikleri ve geri dönüşü olacağına inandıkları, kayıp yaşamak istemedikleri, kısıtlılıklar ve anlaşmazlıklar varsa devam etmek istemedikleri, risk almak istemedikleri ve batık maliyet, fırsat maliyetleri, değişimleri düşündükleri anlaşılmaktadır.

Tablo 1. Kişiliğin Hatalı Karar Bağlılığı Üzerindeki Etkileri

\begin{tabular}{|c|c|c|c|c|c|}
\hline & \multicolumn{2}{|c|}{ Model Özeti } & \multicolumn{3}{|c|}{ ANOVA } \\
\hline $\mathrm{R}$ & $R^{2}$ & Düzelt. $R^{2}$ & $\mathrm{~F}$ & & Anlamlılık \\
\hline .316 & .100 & .065 & 2.891 & & .016 \\
\hline \multicolumn{6}{|c|}{ Korelasyonlar } \\
\hline & \multicolumn{2}{|c|}{ Standart Olmayan Katsayılar } & \multicolumn{2}{|c|}{ Standart Katsayılar } & \\
\hline & $\mathrm{B}$ & Std. Sapma & $B$ & $\mathrm{t}$ & Anlamlılık \\
\hline Sabit Değer & 3.603 & .402 & & 8.972 & .000 \\
\hline Dişadönüklük & 0.059 & .057 & .090 & 1.036 & .302 \\
\hline Uyum & -.159 & .063 & -.214 & -2.516 & .013 \\
\hline Sorumluluk & .175 & .067 & .239 & 2.609 & .010 \\
\hline Duygusal Denge & -.046 & .062 & -.068 & -.750 & .455 \\
\hline Açıklık/Deneyime Açıklık & -.023 & .069 & -.028 & -.328 & .743 \\
\hline
\end{tabular}

Tablo 2. Duygusal Zekanın Hatalı Karar Bağlılığı Üzerindeki Etkileri

\begin{tabular}{|c|c|c|c|c|c|}
\hline & \multicolumn{2}{|c|}{ Model Özeti } & \multicolumn{3}{|c|}{ ANOVA } \\
\hline $\mathrm{R}$ & $R^{2}$ & Düzelt. $R^{2}$ & $\mathrm{~F}$ & & Anlamlılık \\
\hline .278 & .077 & .070 & 11.265 & & .001 \\
\hline \multicolumn{6}{|c|}{ Korelasyonlar } \\
\hline & \multicolumn{2}{|c|}{ Standart Olmayan Katsayılar } & \multicolumn{2}{|c|}{ Standart Katsayılar } & \\
\hline & $\mathrm{B}$ & Std. Sapma & B & $\mathrm{t}$ & Anlamlılık \\
\hline Sabit Değer & 1.848 & .552 & & 3.345 & .001 \\
\hline Duygusal Zekâ & .474 & .141 & .278 & 3.356 & .001 \\
\hline
\end{tabular}


Tablo 3. Öz Yeterliliğin Hatalı Karar Bağlılığı Üzerindeki Etkileri

\begin{tabular}{|c|c|c|c|c|c|}
\hline & \multicolumn{2}{|c|}{ Model Özeti } & \multicolumn{3}{|c|}{ ANOVA } \\
\hline $\mathrm{R}$ & $R^{2}$ & Düzelt. $R^{2}$ & $\mathrm{~F}$ & & Anlamlılık \\
\hline .311 & .097 & .076 & 4.753 & & .004 \\
\hline \multicolumn{6}{|c|}{ Korelasyonlar } \\
\hline & \multicolumn{2}{|c|}{ Standart Olmayan Katsayılar } & \multicolumn{2}{|c|}{ Standart Katsayılar } & \\
\hline & B & Std. Sapma & B & $\mathrm{t}$ & Anlamlılık \\
\hline Sabit Değer & 2.309 & .393 & & 5.882 & .000 \\
\hline Başlama & .267 & .121 & .247 & 2.212 & .029 \\
\hline Mücadele & .047 & .103 & .052 & .461 & .646 \\
\hline Sosyal & .068 & .094 & .064 & .720 & .473 \\
\hline
\end{tabular}

Yukarıdaki tablolara göre (Gürbüz ve Şahin, 2016: 270-275), hatalı karar bağlılı̆̆ındaki değișimin \%6.5'i (Düzelt. $R^{2}$ ) kişilik özelliklerinden uyum ve sorumluluk (Tablo 1) ile istatistiki anlamlı olarak açıklanmaktadır [ $\mathrm{F}=2.891, \mathrm{p}<.05]$ özelliklerinden insanlara güven ve iș birliğiyle tanımlanan uyum kişilik özelliğinin (Johnson, 2014: 82) istatistiki olarak anlamlı ve olumsuz etkili olduğu ( $(B=-.214$, $\mathrm{p}<.05$ ) ve başarı, düzen, göreve saygıyla tanımlanan sorumluluk özelliğinin (Johnson, 2014: 82-83) ise hatalı karar bağlılığında istatistiki olarak anlamlı ve olumlu etkili olduğu $(ß=.239, p<.01)$ bulunmuştur. Hatalı karar bağlılığı, sorumluluk özelliğiyle de ilgili ancak bu araştırmada incelenmeyen kişinin kendini cezalandırmasıyla da ilișkili araștırılabilir. Ayrıca, hatalı karar bağlılığında değișimin \%7'si (Düzelt. $R^{2}$ ) duygusal zekâ (Tablo 2) ile istatistiki anlamlı olarak açıklanmaktadır [F=11.265, $\left.\mathrm{p}<.01\right]$. Kişilerin duygusal zekâlarının hatalı karar bağlılığı üzerinde istatistiki anlamlı ve olumlu etkili olduğu $(ß=.278, \mathrm{p}<.01)$; duygularını kontrol edebildiklerini düşündükçe daha fazla devam etmeyi tercih ettikleri anlașılmaktadır. Son olarak, hatalı karar bağlılığındaki değișimin \%7.6'sı (Düzelt. $R^{2}$ ) öz yeterlilik boyutlarından işe başlama öz yeterliliği (Tablo 3) ile istatistiki anlamlı olarak açıklanmaktadır [F=4.753, p<.01). Yapılacak bir şeyi yapmaya başlama konusunda öz yeterliliğin de hatalı karar bağlılı̆̆ını arttırdığı $(ß=.247, \mathrm{p}<.05)$ görülmektedir.

Tablo 4. Başlama Öz Yeterliliğinin Hatalı Karar Bağlılığındaki Etkisinde Cinsiyetin Biçimlendirici Etkisi

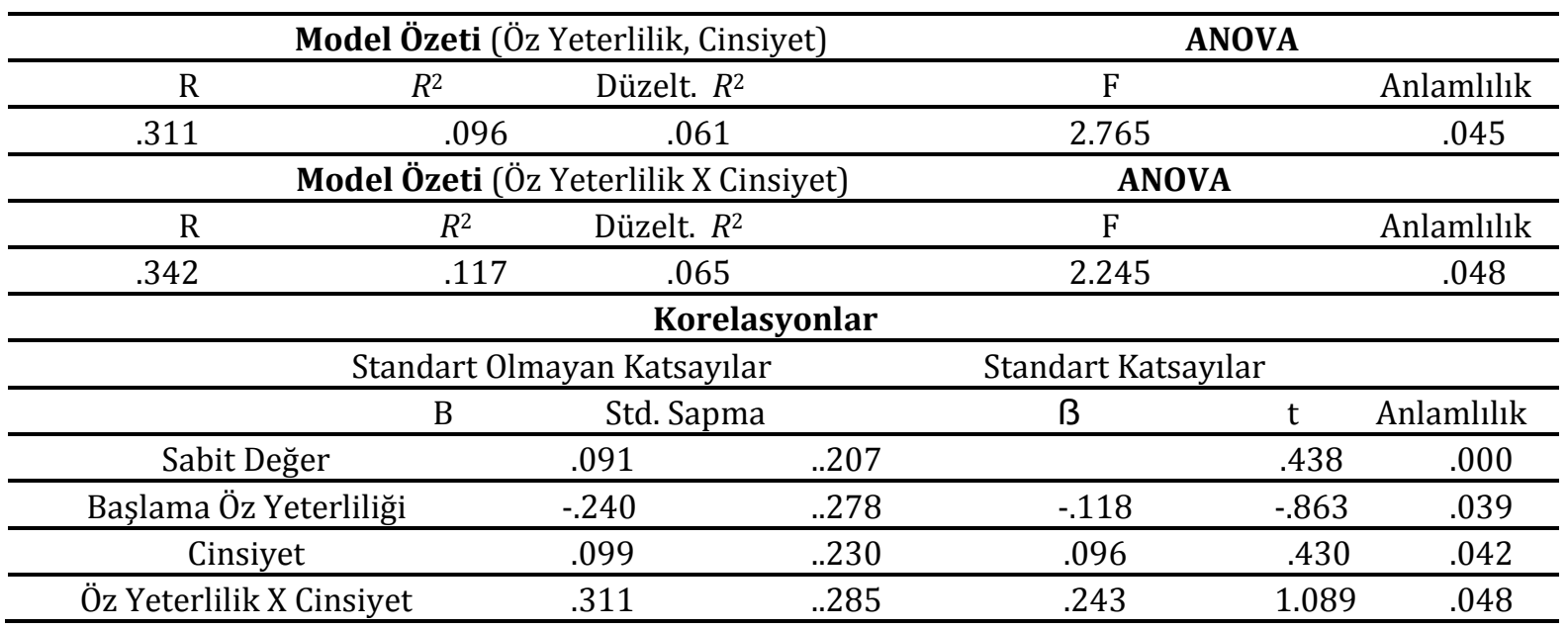

Tablo 4'te yapılan hiyerarşik regresyon analiziyle (Gürbüz ve Şahin, 2016: 294-307), birinci adımda başlama öz yeterliliğinin ve cinsiyetin hatalı karar bağlılığındaki değişimin \%6'sını anlamlı ( $\mathrm{p}<.05)$ açıkladığı görülmektedir. İkinci adımda regresyona girilen iki değişkenin etkileșimsel etkileri ise, hatalı karar bağlılığındaki değişimin \%6.5'unu açıklamakta olup bu katkı anlamlıdır ( $\mathrm{p}<.05)$. Grafik 1'e göre, kadınlar için başlama öz yeterliliği arttıkça hatalı karar bağlılığı az artmaktayken, erkekler için başlama öz yeterliliği arttıkça hatalı karara bağlılık ivmeyle artmaktadır. 
Grafik1. Başlama Öz Yeterliliğin Hatalı Karar Bağlılığındaki Etkisinde Cinsiyetin Biçimlendirici Etkisi

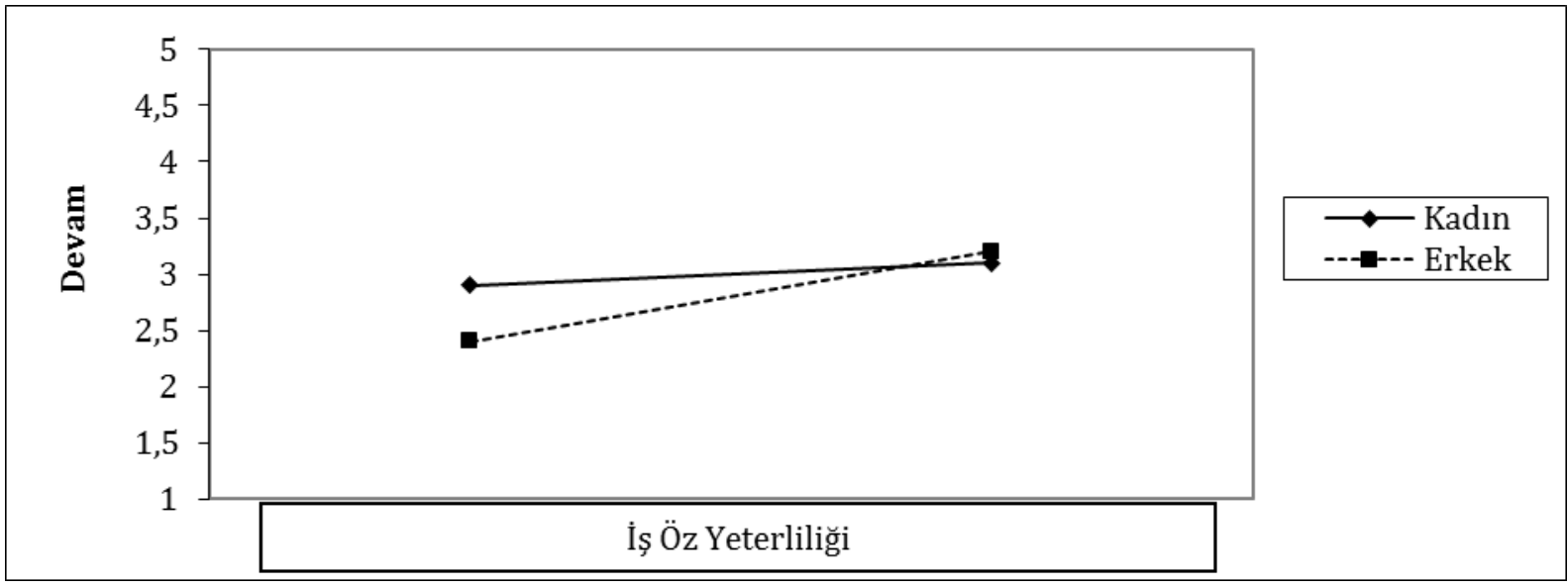

Tablo 5. Duygusal Zekanın Hatalı Karar Bağlılığındaki Etkisinde Cinsiyetin Biçimlendirici Etkisi

\begin{tabular}{|c|c|c|c|c|c|c|}
\hline \multicolumn{4}{|c|}{ Model Özeti (Duygusal Zekâ, Cinsiyet) } & \multicolumn{3}{|c|}{ ANOVA } \\
\hline $\mathrm{R}$ & $R^{2}$ & Düzel & & $\mathrm{F}$ & & Anlamlılık \\
\hline \multirow[t]{2}{*}{.414} & .172 & & & 5.389 & & .007 \\
\hline & \multicolumn{3}{|c|}{ Model Özeti (Duygusal Zekâ X Cinsiyet) } & \multicolumn{2}{|c|}{ ANOVA } & \\
\hline $\mathrm{R}$ & $R^{2}$ & Düzel & & $\mathrm{F}$ & & Anlamlılık \\
\hline \multirow[t]{4}{*}{.439} & \multirow{2}{*}{\multicolumn{3}{|c|}{$\begin{array}{l}.145 \\
\text { Korelasyonlar } \\
\end{array}$}} & 4.063 & & .012 \\
\hline & & & & & & \\
\hline & \multicolumn{3}{|c|}{ Standart Olmayan Katsayılar } & \multicolumn{2}{|c|}{ Standart Katsayılar } & \\
\hline & $\mathrm{B}$ & Std. S & & $B$ & $\mathrm{t}$ & Anlamlılık \\
\hline $\mathrm{Sab}$ & Değer & -.038 &. .178 & & -.213 & .000 \\
\hline Duyg & al Zekâ & .028 &. .261 & .014 & .106 & .010 \\
\hline & yet & .307 &. .165 & .298 & 1.863 & .032 \\
\hline Duygusal 2 & â X Cinsiyet & .320 & .276 & 185 & 1.159 & .012 \\
\hline
\end{tabular}

Not: Her iki hiyerarşik regresyon analizi için tüm ölçek puanları analiz öncesinde standart puanlara dönüştürülmüştür.

${ }^{*} \mathrm{p}<.05,{ }^{* *} \mathrm{p}>.01,{ }^{* * *} \mathrm{p}<.001$

Tablo 5'te yapılan hiyerarşik regresyon analiziyle (Gürbüz ve Şahin, 2016: 294-307), birinci adımda duygusal zekanın ve cinsiyetin hatalı karar bağlılığındaki değiş̧imin \%14'ünü anlamlı ( $\mathrm{p}<.01)$ açıkladığı görülmektedir. İkinci adımda regresyona girilen iki değișkenin etkileșimsel etkileri ise, hatalı karar bağlılığındaki değişimin \%14.5'unu açıklamakta olup bu katkı anlamlıdır ( $\mathrm{p}<.05)$. Grafik 2'ye göre, kadınların duygusal zekâları arttıkça hatalı karar bağlılığı erkeklere göre daha fazla artmaktadır.

Grafik 2. Duygusal Zekanın Hatalı Karar Bağlılığındaki Etkisinde Cinsiyetin Biçimlendirici Etkisi

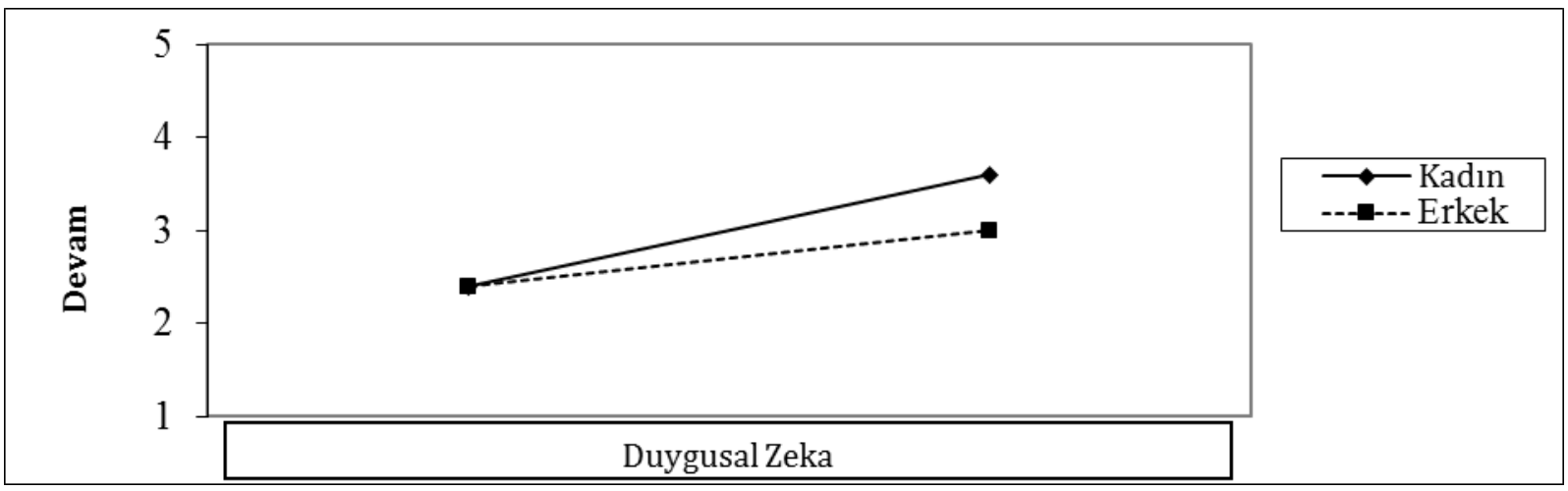




\section{SONUÇ}

$\mathrm{Bu}$ çalışmanın sonucunda proje belirleyicilerinden karar riski ve potansiyel kayıpları anlayabilme hatalı karar bağlılığıyla olumsuz ilişkili; psikolojik belirleyicilerden katkı, güven ve sorumluluk ve sosyal belirleyicilerden de çevreyle anlaşmazlık yaşamama isteği olumlu ilişkili bulunmuştur. Özellikle erkekler için işle/görevle ilgili sorumluluğun hatalı karar bağlılığını arttırdığı ve kadınlar için ise duygusal zekanın hatalı karar bağlılığını arttırdığı görülmektedir.

Zemke vd. (2000:144) Y kuşağının varlıklarının aynı anda çoklu görev yapması ve teknolojik uygulama bilgisi olması, yükümlülüklerinin ise işte yetişme ve kişilerarası konularda deneyim kazanması olduğunu belirtmiştir. Bu araştırmanın sonuçlarına göre de kişilerin psikolojik ve sosyal etkileri değerlendirerek kararlarını daha iyi verebilecekleri anlaşılmaktadır.

Drummond (2014: 438-442) bu konuyla ilgili işi/projeyi takip etmenin, başarısızlık döngüsünü kırmak için yeterli iyimserlik göstermenin, fırsat maliyetleriyle devamlılı̆̆ın görünmeyen yararlarını değerlendirmenin, devam ya da tamam için iyi nedenleri düşünmenin, Janus yüzünü benimsemenin, dışarıdan bakış açısı almanın, şüphe, çelişki, anlaşmazlık, diğer düşünceler yerine yola odaklanmanın, şans ve sezgiyi unutmamanın önemli olduğunu belirtmiştir.

Bu konu kapsamında, istihdamlarıyla ilgili çeşitli sektörlerde çalışanlarla yapılacak araştırmalar da sektörel olarak belirli bir ölçüde temsil edici ve yararlı olabilir ve farklı kuşaklarda da aynı özelliklerin mi önemli olduğu araștırılabilir. Bu araștırma daha büyük örneklemlerde ve farklı kültürlerde yapılabilir ve cinsiyetler arasındaki farklılar incelendiğinde hangi özelliklerin vurgulandığına bakılabilir. Ayrıca, gelecek araştırmalarda, duygular, güdüler ve takım dinamikleri de değerlendirebilir.

\section{KAYNAKÇA}

Alvarez, J.F.A, Pustina, A. \& Hällgren, A. (2011). Escalating Commitment in the Death Zone. New insights from the 1996 Mount Everest Disaster. International Journal of Project Management, 29, 971-985.

Bandura, A. (2009). Self Efficacy in Changing Societies. Cambridge University Press, 1-351.

Chong, V.K. \& Syarifuddin, I. (2010). Escalation of Commitment to Unprofitable Projects: An Experimental Investigation of the Effect of Conformity Pressure and Self Esteem. Accounting, Accountability, and Performance, 16 (1), 1-23.

Deal, J. J., Altman, D. G. \& Rogelberg, S. G. (2010). Millenials at Work: What We Know and What We Need to Do (If Anything). Journal of Business Psychology, 25, 191-199, Doi: 10.1007/s10869010-9177-2.

Drummond, H. (2014) Escalation of Commitment: When to Stay the Course? The Academy of Management Perspectives, 28 (4), 430-446.

Johnson, J. A. (2014). Measuring Thirty Facets of the Five Factor Model with a 120-Item Public Domain Inventory: Development of the IPIP-NE0-120. Journal of Research in Personality, 51, 78-89. http://dx.doi.org/10.1016/j.jrp.2014.05.003.

Juliusson, A. (2006). Optimism as Modifier of Escalation of Commitment. Scandinavian Journal of Psychology, 47, 345-348.

Goleman, D. (1998). Duygusal Zekâ. Varlık Yayınları, 1-448.

Gürbüz, S. ve Şahin, F. (2016). Sosyal Bilimlerde Araştırma Yöntemleri. Seçkin Yayıncılık, 3. Basım, 1472.

http://www.jeremydawson.co.uk/slopes.htm. Two way with binary moderator.

Kahneman, D. (2017). Hızlı ve Yavaş Düşünme. Varlık Yayınları, 1-568.

Krogerus, M. \& Tschäppeler, R. (2014). The Test Book. 64 Tools to Lead You Success. Profile Books. London, 1-200.

$\mathrm{Ku}, \mathrm{G}$. (2008). Learning to De Escalate. The Effects of Regret in Escalation of Commitment. Organizational Behavior and Human Decision Process, 105, 221-232. 
Luthans, F. (2011) Organizational Behavior. An Evidence Based Approach. 12th Ed. The McGraw Hill Companies, Inc. 1-594.

Ordun, G. ve Akün, A. (2017). Self Actualization, Self Efficacy and Emotional Intelligence of Undergraduate Students, Journal of Advanced Management Science, 5 (3), 170-175.

Schuette, N. S., Malouff, J. M., Hall, L. E, Haggerty, D. J, Cooper, J. T., Golden, C. J. \& Dornheim, L. D. (1998) Development and Validation of a Measure of Emotional Intelligence. Personality and Individual Differences, 25, 167-177.

Sherer, M. \& Maddux, J. E. (1982). The self-efficacy scale: Construction and Validation, Psychological Reports, vol. 51, pp. 663-671.

Sleesman, D.J., Conlon, D.E., McNamara, G. \& Miles, J.E. (2012). Cleaning up the Big Muddy: A Meta Analytical Review of the Determinants of Escalation of Commitment. Academy of Management Journal, 55 (3), 541-562.

Staw, B. M. \& Ross, J. (1987). Behavior in Escalation Situations: Antecedents, Prototypes, and Solutions. In L. L. Cummings \& B. M. Staw (Eds.), Research in Organizational Behavior, 9, 39-78. Greenwich, CT: JAI.

Zemke, R., Raines, C., \& Filipczak, B. (2000). Genarations at Work. Managing the Clash of Veterans, Boomers, Xers, and Nexters in Your Workplace. Performance Research Associates, Inc., 1-280. 